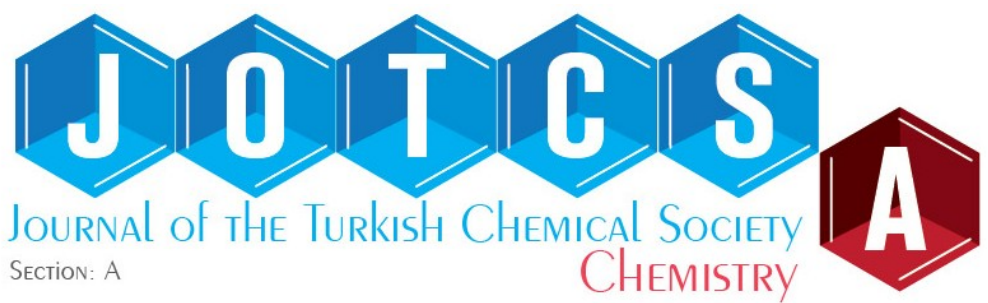

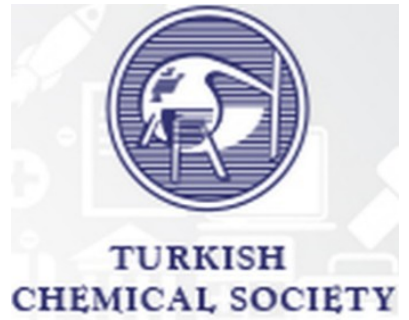

\title{
Chemical Composition and Antioxidant Activities of Leaf and Flower Essential Oils of Origanum onites L. (Lamiaceae) Growing in Mount Ida- Turkey
}

\author{
Züleyha Özer ${ }^{*}$
}

${ }^{1}$ University of Balıkesir, Altınoluk Vocational School, Programme of Medicinal and Aromatic Plants, 10870 Balıkesir, TURKEY

Abstract: The chemical composition of leaf and flower essential oils of Origanum onites L. were analyzed using Thermo Scientific TSQ GC-MS/MS. Also, antioxidant activities of the leaf and flower essential oils were investigated by using DPPH (1,1-diphenyl-2-picrylhydrazyl) free radical scavenging activity and $\beta$ carotene linoleic acid assays. BHA (Butylated hydroxyanisole) and BHT (Butylated hydroxytoluene) were used as standards. The essential oil yields of $O$. onites were $1.75 \%$ for leaves and $4.25 \%$ for flowers. A total of twenty-three compounds representing $99.9 \%$ of leaf oil and twenty-four compounds constituted $99.6 \%$ of the flower oil were determined. Oxygenated monoterpenes were detected at a high percentage $(69.2 \%)$ in leaf essential oil, and carvacrol $(64.9 \%)$ was determined as the main compound. Also, flower essential oil was dominated by sesquiterpene hydrocarbons $(73.5 \%)$, and a-cubebene $(36.4 \%)$ was determined as a primary compound. For leaf oil, a high antioxidant capacity was determined, primarily due to carvacrol and $p$-cymene.

Keywords: Origanum onites, essential oil, carvacrol, a-cubebene, antioxidant activity.

Submitted: August 14, 2020. Accepted: September 13, 2020.

Cite this: Özer Z. Chemical Composition and Antioxidant Activities of Leaf and Flower Essential Oils of Origanum onites L. (Lamiaceae) Growing in Mount Ida-Turkey. JOTCSA. 2020;7(3):813-20.

DOI: https://doi.org/10.18596/jotcsa.780334.

*Corresponding author. E-mail: zuleyhaozer@balikesir.edu.tr, Tel: +90 2663961552.

\section{INTRODUCTION}

Plants have been one of the necessary, indispensable resources of life since ancient times. People have used plants not only for nutrition but also for the treatment of various diseases (1). Nowadays, medicinal and aromatic plants are used in food, cosmetics, paint, textile, medicine, and agriculture (2).

Lamiaceae (Labiatae) family, which is rich in medicinal plants, is usually one or perennial herbaceous plants containing essential oil. Turkey is an important center in terms of gene Lamiaceae plants $(3,4)$. The genus Origanum L. is one of the most widely used genera of the Lamiaceae family. The genus Origanum has 21 species (24 taxa) and 13 hybrids in Turkey (5-7). The pharmacological and biological activities of Origanum species mostly due to the antioxidant, antimicrobial, anticancer, analgesic, antiradical, antibacterial, cytotoxic, antifungal, and insecticidal activities of their essential oils (8-14).

O. onites L. (Turkish oregano), leaves, flowers, and essential oils of this plant are used in herbal tea, medicine, food, cosmetics, and perfumery industries. It is also named as 'kırkbas kekik', 'bilya kekik', 'tokalı kekik', 'koca lealı kekik', 'arı kekiği' in vernacular (15). The infusion prepared from the above-ground parts of this species is used in the treatment of diseases and symptoms such as gastrointestinal diseases, diabetes, dyspepsia, carminative, bronchitis, respiratory tract diseases, cold \& flu, hypertension, and tachycardia by the local people $(1,15,16)$. O. onites is abundantly 
present in the natural habitat of the Mediterranean coastline (17). The essential oil compounds of $O$. onites have been researched earlier from diverse places in the world. The essential oil was comprised of carvacrol as a major compound, followed by thymol, linalool, a-pinene, p-cymene, sabinene hydrate, $\quad$-terpinene, a-terpinene (17-23). The essential oil of $O$. onites has antioxidant (23-26), antimicrobial, antifungal (27), insecticidal (28), larvicidal (29), antidiabetic (30), and cholinesterase inhibitory (31) activities.

The literature abounds with reports regarding the detection of chemical components of the essential oil of $O$. onites aerial parts, and no studies differentiating the essential oils of leaf and flower have been reported to date. Although the essential oils are usually procured from the aerial parts of the herb, this report gives us to see the variation among the components of both parts of the herb. Hence, this report was aimed to identify chemical components and antioxidant activities of leaf and flower essential oils of $O$. onites.

\section{EXPERIMENTAL SECTION}

\section{Plant material}

The aerial parts of 0 . onites $(300 \mathrm{~g})$ were collected from Balıkesir, (Edremit, Altınoluk, Kaz Dağı, Bent Picnic Area) 39०34'51.4"N, 26 45'26.4"E, 100 m, in July 2016 . The investigated species was identified by Prof. Dr. Selami Selvi at Balıkesir University. The voucher specimens were deposited at the Herbarium of the Altınoluk Vocational School, Balıkesir University, Balıkesir, Turkey (Herbarium number SV 1567).

\section{Essential oil}

Fresh leaves and flowers (40 g each) were dried in the shade, chopped into small pieces, and subjected to hydrodistillation with a Clevenger-type apparatus for $4 \mathrm{~h}$. The yields of essential oils are $1.75 \%$ and
$4.25 \%$ from leaf and flower, respectively. They were stored in amber vials at $4^{\circ} \mathrm{C}$ for further analyses.

\section{GC-MS experiments}

GC-MS was conducted on Thermo Scientific TSQ GC-MS/MS. The column used was Rtx-5Sil MS, 30 $\mathrm{m}, 0.25 \mathrm{~mm}$ ID, $0.25 \mu \mathrm{m}$ (32). A detailed procedure was given in the supplementary material.

\section{Antioxidant activity}

The antioxidant activities were measured based on DPPH (1,1-diphenyl-2picrylhydrazyl) free radical scavenging activity (33$36)$ and $\beta$-carotene linoleic acid (34-36) assays. The activity tests were carried on at $10,25,50,100 \mu \mathrm{g} /$ $\mathrm{mL}$ concentrations. $\mathrm{BHA}$ and $\mathrm{BHT}$ were used as standards. $\mathrm{IC}_{50}$ values of all samples were calculated. A detailed procedure was given in the supplementary material.

\section{Statistical analysis}

Antioxidant activity results were evaluated using a One-way ANOVA test (GraphPad, Software version is 8.4.2). $\mathrm{P}<0.05$ was accepted as the minimum level of significance.

\section{RESULTS AND DISCUSSION}

\section{Essential oil}

Higher essential oil yield was obtained from the flower $(4.25 \%)$ compared to the leaf $(1.75 \%)$ essential oil. Altogether, twenty-three compounds representing $99.9 \%$ of leaf essential oil and twentyfour compounds constituted $99.6 \%$ of the flower essential oil were determined. The components of essential oils were classified into 4 based on their chemical structures: monoterpene hydrocarbons, oxygenated monoterpenes, sesquiterpene hydrocarbons and oxygenated sesquiterpenes. The essential oil components of leaves and flowers of $O$. onites are summarized in Table 1.

Table 1: Essential oil compositions of leaf and flower of $O$. onites.

\begin{tabular}{|c|c|c|c|c|c|}
\hline No & Compounds & $\mathbf{R T}^{\mathbf{a}}$ & $\mathbf{K I}^{\mathbf{b}}$ & Leaf (\%) & Flower (\%) \\
\hline 1 & a-thujene & 5.25 & 930 & 1.5 & 0.5 \\
\hline 2 & a-pinene & 5.37 & 939 & 0.5 & 0.2 \\
\hline 3 & camphene & 6.08 & 954 & 0.3 & $t^{c}$ \\
\hline 4 & sabinene & 14.48 & 975 & $t^{c}$ & $t^{c}$ \\
\hline 5 & $\beta$-pinene & 6.70 & 979 & 0.1 & - \\
\hline 6 & a-phellandrene & 7.85 & 1003 & 1.3 & 0.7 \\
\hline 7 & a-terpinene & 8.30 & 1017 & 2.4 & 0.9 \\
\hline 8 & p-cymene & 8.53 & 1025 & 11.2 & 3.9 \\
\hline 9 & $\beta$-phellandrene & 8.70 & 1030 & 0.6 & 0.3 \\
\hline 10 & (E)- $\beta$-ocimene & 9.28 & 1050 & 9.1 & 2.7 \\
\hline 11 & $\mathrm{Y}$-terpinene & 9.39 & 1060 & 0.4 & 0.3 \\
\hline 12 & sabinene hydrate-cis & 17.25 & 1070 & 0.4 & 0.1 \\
\hline 13 & sabinene hydrate-trans & 11.41 & 1098 & 0.2 & 0.1 \\
\hline 14 & $\beta$-cis-terpineol & 13.20 & 1144 & 1.2 & 0.1 \\
\hline 15 & camphor & 18.22 & 1146 & 0.8 & 0.1 \\
\hline 16 & carvacrol, ethyl ether & 20.10 & 1298 & 2.1 & - \\
\hline 17 & carvacrol & 20.14 & 1299 & 64.5 & 16.0 \\
\hline 18 & ס-elemene & 21.77 & 1338 & - & 34.6 \\
\hline 19 & a-cubebene & 22.33 & 1351 & - & 36.4 \\
\hline 20 & a-copaene & 23.49 & 1377 & 0.4 & - \\
\hline
\end{tabular}




\begin{tabular}{|c|c|c|c|c|c|}
\hline 21 & $\beta$-bourbonene & 24.05 & 1388 & - & 0.1 \\
\hline 22 & aromadendrene & 26.27 & 1441 & 1.1 & 1.2 \\
\hline 23 & Z- $\beta$-farnesene & 26.33 & 1443 & 0.1 & 0.1 \\
\hline 24 & a-humulene & 26.82 & 1455 & 0.2 & - \\
\hline 25 & $\mathrm{E}-\beta$-farnesene & 26.92 & 1457 & - & 0.1 \\
\hline 26 & allo-aromadendrene & 27.07 & 1460 & 1.3 & 1.0 \\
\hline 27 & spathulenol & 31.96 & 1578 & 0.2 & 0.1 \\
\hline 28 & a-cadinol & 34.93 & 1654 & - & 0.1 \\
\hline \multirow{4}{*}{\multicolumn{4}{|c|}{$\begin{array}{l}\text { Monoterpene hydrocarbons } \\
\text { Oxygenated monoterpenes } \\
\text { Sesquiterpene hydrocarbons } \\
\text { Oxygenated sesquiterpenes }\end{array}$}} & 27.4 & 9.5 \\
\hline & & & & 69.2 & 16.4 \\
\hline & & & & 3.1 & 73.5 \\
\hline & & & & 0.2 & 0.2 \\
\hline \multicolumn{4}{|c|}{ Total (\%) } & 99.9 & 99.6 \\
\hline \multicolumn{6}{|c|}{$\begin{array}{l}\text { a } \mathrm{RT} \text { : Retention time } \\
{ }^{\mathrm{b}} \mathrm{KI} \text { : Kovats indices } \\
{ }^{\mathrm{c}} \mathrm{t} \text { : trace }(<0.1 \%)\end{array}$} \\
\hline
\end{tabular}

The main components of leaf essential oil were carvacrol $(64.5 \%), p$-cymene $(11.2 \%)$, and $(\mathrm{E})-\beta$ ocimene $(9.1 \%)$, while a-cubebene $(36.4 \%)$, $\delta$ elemene $(34.6 \%)$, and carvacrol $(16.0 \%)$ were determined as the main compounds in the flower essential oil (Figure 1). The leaf essential oil was qualified by the high content of monoterpenes $(96.6 \%)$, including hydrocarbons $(27.4 \%)$ and their oxygenated derivatives $(69.2 \%)$, while sesquiterpenes $(3.3 \%)$ were detected in very low amounts.

Sesquiterpene hydrocarbons (73.5\%) composed the primary class of compound determined in the flower essential oil with a-cubebene (36.4\%) and $\delta$ elemene (34.6\%). Oxygenated monoterpenes and monoterpene hydrocarbons were also detected at an average percentage in flower essential oil (16.4\% and $9.5 \%$, respectively).

The results indicate that the essential oil content of leaf and flower were dissimilar. For example, carvacrol was found mainly in leaf essential oil at $64.5 \%$ against $16.0 \%$ in the flower essential oil. In contrast, a-cubebene (36.4\%) and $\delta$-elemene $(34.6 \%)$, significant compounds of flower essential oil were not detected in leaf essential oil. Also, $\beta$ pinene, carvacrol ethyl ether, a-copaene, and ahumulene were detected only in the leaf essential oil. Also, $p$-cymene and (E)- $\beta$-ocimene were found to be significant compounds in leaf essential oil at 11.2 and $9.1 \%$ against 3.9 and $2.7 \%$ in the flower essential oil, respectively. It is well known that different parts of the same plant may include different phytochemicals $(37,38)$. This variation can be elucidated by the presence of different secretory structures in different plant parts. Dissimilar phytochemicals are available in each of the parts of the plant may explanation for the variation in the pharmacological and biological properties.

Carvacrol, the most abundant compound of the leaf essential oil, was reported in the essential oils of aerial parts of 0 . onites from Turkey $(18,24,29$, $39,40)$ and Greece $(22,23,41,42)$. However, acubebene and $\delta$-elemene were not reported previously as significant components of $O$. onites. aCubebene was detected in low quantities of aerial parts of $O$. onites from Greece (42). Also, Figuérédo et al. reported that $O$. onites was the linalool types (42). Ceylan et al. (2003) reported the essential oil compounds of $O$. onites from eighteen different localities of Turkey, while generally, carvacrol was found to be a significant compound, and only one locality had linalool-rich (43). Lukas et al. (2010) reported that chemotypes of 0 . onites from ten different locations of Turkey and Greece. In Greece location of $O$. onites was found to be "cymyl"chemotypes. In Turkey location of $O$. onites was characterized by linalool and "cymyl"-chemotypes (44). These differences in the chemical composition of essential oil may be due to the environmental, climate conditions, drying methods, harvest period, extraction methods, extraction time, and temperature. These variables affect the vegetative cycle of the herb and subscribe to the chemical variations of its essential oil.
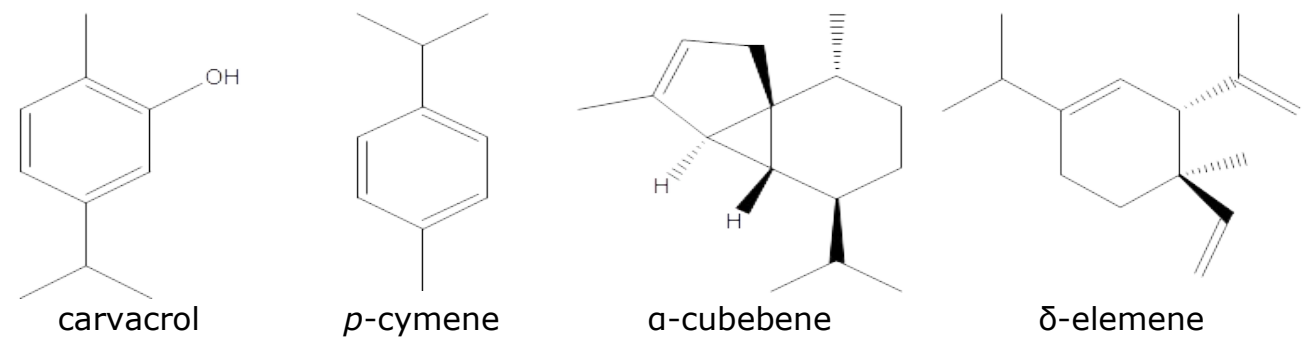

a-cubebene

$\delta$-elemene

Figure 1: Chemical structures of the main compounds of leaf and flower essential oils. 


\section{Antioxidant activity}

DPPH free radical scavenging activity and $\beta$ carotene linoleic acid assays were used to determined antioxidant activities of leaf and flower essential oils of $O$. onites. The $50 \%$ inhibition concentrations $\left(\mathrm{IC}_{50}\right.$ ) results are given in Table 2 . Leaf and flower essential oils have an excellent antioxidant capacity for both tested assays. IC $_{50}$ values for the DPPH of leaf and flower essential oils were found to be $19.05 \pm 3.96 \mu \mathrm{g} / \mathrm{mL}$ and $29.95 \pm$ $5.86 \mu \mathrm{g} / \mathrm{mL}$, respectively. Besides, BHA and BHT $\mathrm{IC}_{50}$ values were found to be $11.73 \pm 2.27 \mu \mathrm{g} / \mathrm{mL}$ and $17.22 \pm 1.55 \mu \mathrm{g} / \mathrm{mL}$. IC $\mathrm{IC}_{50}$ values of leaf and flower essential oil were found to be $22.39 \pm 3.88$ $\mu \mathrm{g} / \mathrm{mL}$ and $30.29 \pm 0.84 \mu \mathrm{g} / \mathrm{mL}$ in the $\beta$-carotene linoleic acid assay, respectively. None of the leaf and flower essential oils showed higher antioxidant activity than BHA or BHT. Low $\mathrm{IC}_{50}$ values reflect a high antioxidant activity. These results revealed that leaf essential oil showed better antioxidant capacity when compared to flower essential oil. Carvacrol and $p$-cymene were reported to play a important role in antioxidant capacity $(45,46)$.

Table 2: Antioxidant capacity of leaf and flower essential oils ( IC $_{50}$ ).

\begin{tabular}{lcc}
\hline & $\boldsymbol{\beta}$-carotene & DPPH \\
\hline Leaf & $22.39 \pm 3.88$ & $19.05 \pm 3.96$ \\
Flower & $30.29 \pm 0.84$ & $29.95 \pm 5.86$ \\
BHA & $14.21 \pm 1.16$ & $11.73 \pm 2.27$ \\
BHT & $17.73 \pm 2.43$ & $17.22 \pm 1.55$ \\
\hline IC 50 values are mean \pm SD $(\mathrm{n}=3)$.
\end{tabular}

\section{CONCLUSION}

The chemical contents of leaf and flower essential oils of $O$. onites were investigated. Also, the antioxidant activity of the essential oils was determined. In this study, it was found that the leaf essential oil was found as carvacrol type, and flower essential oil was the a-cubebene type. It can be said that the quantitative and qualitative differences of essential oils depend on different secretory structures in different plant parts. To the best of our knowledge, this is the first report on the chemical components and antioxidant activities of leaf and flower essential oils of $O$. onites. The leaf and flower essential oils of $O$. onites have the good antioxidant capacity. Thus, the essential oils from both parts of $O$. onites may be regarded as possible natural antioxidant agents for cosmetic, food and pharmaceutical industries.

\section{Supplementary data}

Inhibition (\%) of lipid peroxidation and DPPH free radical scavenging activity, Gas chromatographyMass spectrometry conditions and antioxidant activities procedures were given in supplementary material.

\section{REFERENCES}

1. Baytop T. Türkiye'de Bitkiler İle Tedavi, Geçmişte ve Bugün. İstanbul: İstanbul Üniversitesi, Eczacılık Fakültesi; 1999. 550s p.

2. Vergine $M$, Nicolì $F$, Negro $C$, Luvisi $A$, Nutricati E, Accogli RA, Sabella $E$, Miceli A. Phytochemical Profiles and Antioxidant Activity of Salvia Species from Southern Italy. Rec Nat Prod. 2019;13(3):205-15.

3. Mokhtarzadeh $S$, Demirci B, Ağalar HG, Khawar KM, Kırımer N. In vitro Propagation and
Volatile Compound Characterization of Lavandula stoechas L. subsp. stoechas-An Economically Important Source of Essential Oil. Rec Nat Prod. 2019;13(2):121-8.

4. Davis PH. Flora of Turkey and The East Agean Islands. Labiatae. University. Edinburg; 1982. 462-463 p.

5. Arabaci T, Dirmenci T, Yıldız B. Origanum L. (Ballıbabagiller/Lamiaceae) Cinsine Ait Yeni Bir Melez: Origanum $\times$ malatyanum Yıldız, Arabacı \& Dirmenci. Bağbahçe Bilim Dergisi. 2020;7(1):10-5.

6. Özer Z, Gören AC, Kılıç T, Öncü M, Çarıkçı S, Dirmenci T. The Phenolic Contents, Antioxidant and Anticholinesterase Activity of Section Amaracus (Gled.) Vogel and Anatolicon Ietsw. of Origanum L. Species. Arab J Chem. 2020;13(4):5027-39.

7. Dirmenci T, Yazici T, Özcan T, Çelenk S, Martin E. A New Species and a New Natural Hybrid of Origanum L. (Lamiaceae) from the West of Turkey. Turk J Botany. 2018;42(1):73-90.

8. Fotakis C, Tsigrimani D, Tsiaka $T$, Lantzouraki DZ, Strati IF, Makris C, et al. Metabolic and Antioxidant Profiles of Herbal Infusions and Decoctions. Food Chem [Internet]. 2016;211:963$71 . \quad$ Available from: http://dx.doi.org/10.1016/j.foodchem.2016.05.124

9. Hajlaoui $H$, Mighri $H$, Aouni M, Gharsallah $N$, Kadri A. Chemical Composition and in vitro Evaluation of Antioxidant, Antimicrobial, Cytotoxicity and Anti-acetylcholinesterase Properties of Tunisian Origanum majorana L. Essential Oil. Microb Pathog. 2016;95:86-94.

10. Yan F, Azizi A, Janke S, Schwarz M, Zeller S, Honermeier B. Antioxidant Capacity Variation in the 
Oregano (Origanum vulgare L.) Collection of the German National Genebank. Ind Crops Prod [Internet]. 2016;92:19-25. Available from: http://dx.doi.org/10.1016/j.indcrop.2016.07.038

11. Aykac A, Becer E, Özbeyli D, Şener G, Başer KHC. Protective Effects of Origanum onites Essential Oil in the Methotrexate-Induced Rat Model: Role on Apoptosis and Hepatoxicity. Rec Nat Prod. 2020;14(6):395-404.

12. Sivropoulou A, Papanikolaou E, Nikolaou C, Kokkini S, Lanaras T, Arsenakis M. Antimicrobial and Cytotoxic Activities of Origanum Essential Oils. ] Agric Food Chem. 1996;44(5):1202-5.

13. Hanana $M$, Mansour MB, Algabr M, Amri I Gargouri S, Romane A, ... \& Hamrouni L. Potential Use of Essential oils from Four Tunisian Species of Lamiaceae: Biological Alternative for Fungal and Weed Control. Rec Nat Prod. 2017;11(3):258-69.

14. Pavela R. Insecticidal Activity of Certain Medicinal Plants. Fitoterapia. 2004;75(7-8):745-9.

15. Sargin SA, Akçicek E, Selvi S. An Ethnobotanical Study of Medicinal Plants Used by the Local People of Alaşehir (Manisa) in Turkey. J Ethnopharmacol. 2013;150(3):860-74.

16. Selvi $\mathrm{S}$, Dağdelen $\mathrm{A}$, Kara $\mathrm{S}$. Kazdağlarından (Balıkesir-Edremit) Toplanan ve Çay Olarak Tüketilen Tıbbi ve Aromatik Bitkiler. Journal of Tekirdag Agricultural Faculty. 2013;10(2):26-33.

17. Tepe B, Cakir A, Sihoglu Tepe A. Medicinal Uses, Phytochemistry, and Pharmacology of Origanum onites (L.): A Review. Chem Biodivers. 2016;13(5):504-20.

18. Korukluoglu M, Gurbuz O, Sahan Y, Yigit A, Kacar O. Rouseff R. Chemical Characterization and Antifungal Activity of Origanum onites L. Essential Oils and Extracts. J Food Saf. 2008;29(2009):14461.

19. Ozkan G, Baydar H, Erbas S. The Influence of Harvest Time on Essential Oil Composition, Phenolic Constituents and Antioxidant Properties of Turkish Oregano ( Origanum onites L .). J Sci Food Agr. 2010;90(2):205-9.

20. Vokou D, Kokkini S, BessiÈRe JM. Origanum onites (Lamiaceae) in Greece: Distribution, Volatile Oil Yield, and Composition. Econ Bot. $1988 ; 42(3): 407-12$.

21. Spyridopoulou K, Fitsiou E, Bouloukosta E, Tiptiri-Kourpeti A, Vamvakias M, Oreopoulou A, et al. Extraction, Chemical Composition, and Anticancer Potential of Origanum onites L. Essential Oil. Molecules. 2019;24(14):2612.
22. Stefanakis MK, Touloupakis E, Anastasopoulos E, Ghanotakis D, Katerinopoulos HE, Makridis P. Antibacterial Activity of Essential Oils from Plants of the Genus Origanum. Food Control [Internet]. 2013;34(2):539-46. Available from: http://dx.doi.org/10.1016/j.foodcont.2013.05.024

23. Lagouri V, Blekas G, Tsimidou M, Kokkini S, Boskou D. Composition and Antioxidant Activity of Essential Oils from Oregano Plants Grown Wild in Greece. Z Lebensm Unters Forsch. 1993;197(1):203.

24. Özkan A, Erdoğan A. A Comparative Evaluation of Antioxidant and Anticancer Activity of Essential Oil from Origanum onites (Lamiaceae) and its Two Major Phenolic Components. Turkish J Biol. $2011 ; 35(6): 735-42$.

25. Ozdemir N, Ozgen Y, Kiralan M, Bayrak A, Arslan N, Ramadan MF. Effect of Different Drying Methods on the Essential Oil Yield, Composition and Antioxidant Activity of Origanum vulgare L. and Origanum onites L. J Food Meas Charact [Internet]. 2018;12(2):820-5. Available from: http://dx.doi.org/10.1007/s11694-017-9696-x

26. Semiz G, Semiz A, Mercan-Doğan N. Essential Oil Composition, Total Phenolic Content, Antioxidant and Antibiofilm Activities of Four Origanum Species from Southeastern Turkey. Int J Food Prop [Internet]. 2018;21(1):194-204. Available https://doi.org/10.1080/10942912.2018.1440240

27. Altintas A, Tabanca N, Tyihák E, Ott PG, Móricz ÁM, Mincsovics $E$, et al. Characterization of Volatile Constituents from Origanum onites and Their Antifungal and Antibacterial Activity. J AOAC Int. $2013 ; 96(6): 1200-8$.

28. Yildirim E, Kordali S, Yazici G. Insecticidal Effects of Essential Oils of Eleven Plant Species from Lamiaceae on Sitophilus granarius (L.) (Coleoptera: Curculionidae). Rom Biotechnol Lett. 2011;16(6):6702-9.

29. Erler $F$, Cetin $H$. Components from the Essential Oils from Two Origanum Species as Larvicides against Euproctis chrysorrhoea (Lepidoptera: Lymantriidae). J Agric Urban Entomol. 2009;26(1):31-40.

30. Lermioglu F, Bagci S, Onderoglu S, Ortac R, Tugrul L. Evaluation of the Long-term Effects of Oleum Origani on the Toxicity Induced by Administration of Streptozotocin in Rats. J Pharm Pharmacol. 1997;49(11):1157-61.

31. Orhan I, Şener B, Kartal M, Kan Y. Activity of Essential Oils and Individual Components against 
Acetyl-and Butyrylcholinesterase. Zeitschrift fur Naturforsch - Sect C J Biosci. 2008;63(7-8):54753.

32. Özer Z, Kiliç T, Selvi S, Pasa C. Effect of Different Drying Methods and Development Stages on the Essential Oil Chemical Composition of Aerial Parts of Origanum vulgare L. subsp. hirtum (link) Letsw. J Essent Oil-Bearing Plants. 2018;21(5):1403-09.

33. Blois MS. Antioxidant Determinations by the Use of A Stable Free Radical. Nature. $1958 ; 181: 1199-2000$.

34. Miller H.E. A Simplified Method for the Evaluation of Antioxidants. J Am Oil Chem Soc. $1971 ; 48(2): 91$.

35. Özer Z. Investigation of Phenolic Compounds and Antioxidant Activity of Mentha spicata subsp. spicata and $M$. longifolia subsp. typhoides (briq.) Harley Decoction and Infusion. ] Turkish Chem Soc Sect A Chem. 2018;5(2):445-56.

36. Özer Z. The Phenolic Compounds, Antioxidant and Anticholinesterase Activities of Cyclotrichium origanifolium (Labill.) manden \& scheng and Thymus sipyleus Boiss Teas from Turkey. Stud Univ Babes-Bolyai Chem. 2019;64(3):217-28.

37. Liang $X, B i$, Li F, Wang L. Chemical Compounds from the Twigs and Leaves of Caesalpinia cucullata Roxb. Rec Nat Prod. 2019;13(6):462-7.

38. Trung HD, Thang TD, Khôi NK, Dai DN, Ogunwande IA. Chemical Constituents of Essential Oils from the Leaf, Flower and Fruit of Zanthoxylum avicenna (Lam.) DC. (Rutaceae) from Vietnam. J Essent Oil-Bearing Plants. 2016;19(4):1019-24.

39. Arslan M, Uremis I, Demirel N. Effects of Sage Leafhopper Feeding Damage on Herbage Colour, Essential Oil Content and Compositions of
Turkish and Greek Oregano. Exp Agric. 2012;48(3):428-37.

40. Bostancioĝlu RB, Kürkçüoĝlu $M$, Başer KHC, Koparal AT. Assessment of Anti-Angiogenic and Anti-Tumoral Potentials of Origanum onites L. Essential Oil. Food Chem Toxicol. 2012;50(6):20028.

41. Kokkini S, Karousou R, Hanlidou E, Lanaras T. Essential Oil Composition of Greek (Origanum vulgare ssp. hirtum) and Turkish ( $O$. onites) Oregano: A Tool for Their Distinction. J Essent Oil Res. $2004 ; 16(4): 334-8$.

42. Figuérédo $G$, Cabassu $P$, Chalchat JC, Pasquier B. Studies of Mediterranean Oregano Populations. VII: Chemical Composition of Essential Oils of Carvacrol-rich Oregano of Various Origins. J Essent Oil Res. 2006;18(3):244-9.

43. Ceylan, A., Bayram, E., Sahbaz, N., Otan, H., Karaman S. Yield Performance and Essential Oil Composition of Individual Plants and Improved Clones of Origanum onites L. Grown in the Aegean region of Turkey. Isr J Plant Sci. 2003;51(4):28590.

44. Lukas, B., Samuel, R., Novak J. Oregano or Marjoram? The Enzyme $Y$-terpinene Synthase Affects Chemotype Formation in the Genus Origanum. Isr J Plant Sci. 2010;58(3-4):211-20.

45. Sarikurkcu C, Zengin G, Oskay M, Uysal S, Ceylan R, Aktumsek A. Composition, Antioxidant, Antimicrobial and Enzyme Inhibition Activities of Two Origanum vulgare Subspecies (subsp. vulgare and subsp. hirtum) Essential Oils. Ind Crops Prod [Internet]. 2015;70:178-84. Available from: http:// dx.doi.org/10.1016/j.indcrop.2015.03.030

46. De Oliveira TM, De Carvalho RBF, Da Costa IHF, De Oliveira GAL, De Souza AA, De Lima SG, et al. Evaluation of $p$-cymene, A Natural Antioxidant. Pharm Biol. 2015;53(3):423-8. 


\section{SUPPLEMENTARY DATA}

\section{Chemical Composition and Antioxidant Activities of Leaf and Flower Essential Oils of Origanum onites L. (Lamiaceae) Growing in Mount Ida- Turkey}

\section{Züleyha Özer ${ }^{*}$}

${ }^{1}$ University of Balıkesir, Altınoluk Vocational School, Programme of Medicinal and Aromatic Plants, 10870 Balıkesir, TURKEY

*Corresponding author. E-mail: zuleyhaozer@balikesir.edu.tr, Tel: +90 2663961552

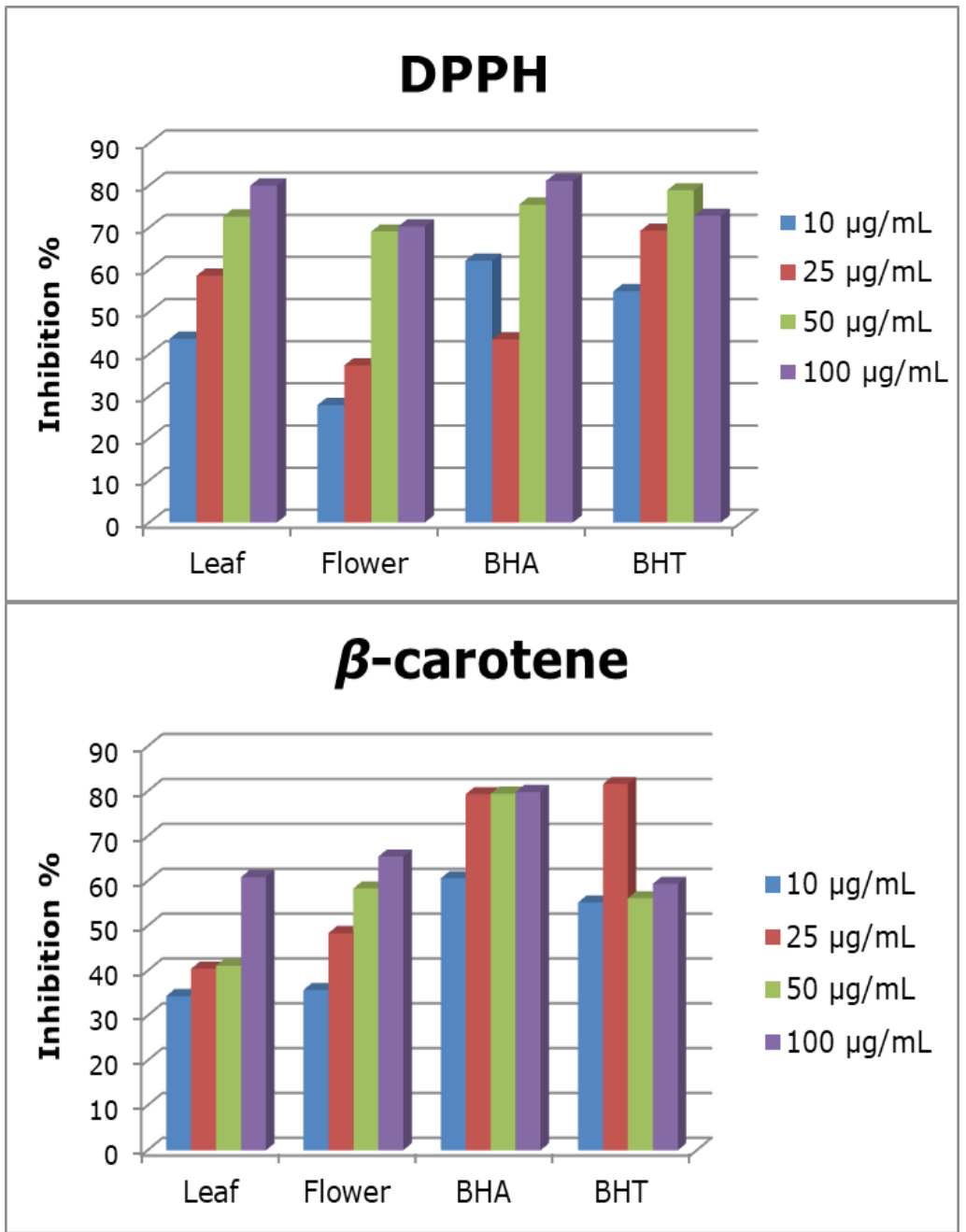

Figure S1. Inhibition (\%) of lipid peroxidation and DPPH free radical scavenging activity of essential oils.

\section{Gas chromatography-Mass spectrometry (GC- MS) conditions}

Helium was used as carrier gas at a constant flow rate of $1 \mathrm{~mL} / \mathrm{min}$ (20 psi). $1 \mu \mathrm{L}$ of the sample was injected (100 $\mu \mathrm{L}$ of essential oil dissolved in $1900 \mu \mathrm{L}$ of dichloromethane). The GC temperature program was set as follows; $150{ }^{\circ} \mathrm{C}$ hold for $5 \mathrm{~min}$, ramp to $250{ }^{\circ} \mathrm{C}$ at $3{ }^{\circ} \mathrm{C} / \mathrm{min}$, and hold for $10 \mathrm{~min}$. The temperature of the MS transfer line was set at 230 ${ }^{\circ} \mathrm{C}$. A mass range from 50 to $650 \mathrm{~m} / \mathrm{z}$ was scanned.
The column used was an Rtx-5Sil MS, $30 \mathrm{~m}, 0.25$ mmID, $0.25 \mu \mathrm{m}$. Thermo Scientific TSQ GC-MS/MS was used in this study. A homologous series of $n-$ alkanes was used as a reference in the calculation of Kovats Indices (KIs). Identification of the compounds was based on the comparison of their relative retention indices and mass spectra with those obtained from authentic samples and the NIST and Wiley spectra as well as the literature data (1). 


\section{Antioxidant activity}

\section{DPPH free radical scavenging method}

The free radical scavenging activity of the extracts was determined spectrophotometrically by the DPPH (1,1-diphenyl-2-picrylhydrazyl) assay (2-5). In its radical form, DPPH absorbs at $517 \mathrm{~nm}$, but upon reduction by an antioxidant or a radical species its absorption decreases. Briefly, $0.1 \mathrm{mM}$ solution of $\mathrm{DPPH}$ in methanol was prepared and $160 \mu \mathrm{L}$ of this solution was added to $40 \mu \mathrm{L}$ of sample solutions in methanol at different concentrations (10, 25, 50, and $100 \mu \mathrm{g} / \mathrm{mL}$ ). These tubes were left in the dark for $30 \mathrm{~min}$. The measurements were made at 517 $\mathrm{nm}$. BHA and BHT were used as standard compounds.

\section{$\boldsymbol{\beta}$-carotene bleaching method}

The antioxidant activity was evaluated using $\beta$ carotene-linoleic acid model system (3-5) $\beta$ carotene $(0.5 \mathrm{mg})$ in $1 \mathrm{~mL}$ of chloroform was added to $25 \mu \mathrm{L}$ of linoleic acid, and $200 \mathrm{mg}$ of Tween 40 emulsifier mixture. After evaporation of chloroform under vacuum, $100 \mathrm{~mL}$ of distilled water saturated with oxygen, was through vigorous shaking. A mixture of $4000 \mu \mathrm{L}$ was transferred into different test tubes containing different concentrations of the sample $(10,25,50$, and $100 \mu \mathrm{g} / \mathrm{mL})$. As soon as the emulsion was added to each tube, the zero time absorbance was measured at $470 \mathrm{~nm}$ using a spectrophotometer. The emulsion system was incubated for $2 \mathrm{~h}$ at $50{ }^{\circ} \mathrm{C}$. A blank, devoid of $\beta$ carotene, was prepared for background subtraction. $\mathrm{BHA}$ and $\mathrm{BHT}$ were used as standard compounds.

\section{REFERENCES}

1. Özer Z, Kiliç T, Selvi S, Pasa C. Effect of Different Drying Methods and Development Stages on the Essential Oil Chemical Composition of Aerial Parts of Origanum vulgare L. subsp. hirtum (link) Letsw. J Essent Oil-Bearing Plants. 2018;21(5):1403-09.

2. Blois MS. Antioxidant Determinations by the Use of A Stable Free Radical. Nature. 1958; 181:1199-2000.

3. Miller H.E. A Simplified Method for the Evaluation of Antioxidants. J Am Oil Chem Soc. $1971 ; 48(2): 91$.

4. Özer Z. Investigation of Phenolic Compounds and Antioxidant Activity of Mentha spicata subsp. spicata and $M$. longifolia subsp. typhoides (briq.) Harley decoction and infusion. J Turkish Chem Soc Sect A Chem. 2018;5(2):445-56.

5. Özer Z. The Phenolic Compounds, Antioxidant and Anticholinesterase Activities of Cyclotrichium origanifolium (Labill.) manden \& scheng and Thymus sipyleus Boiss Teas from Turkey. Stud Univ Babes-Bolyai Chem. 2019;64(3):217-28. 